\title{
EFFECT OF SULFONYLUREAS APPLICATION ON RR/STS SOYBEAN
}

Alfredo Junior Paiola Albrecht ${ }^{1}$, André Felipe Moreira Silva ${ }^{2}$, Leandro Paiola Albrecht ${ }^{1}$, Vinicius Gabriel Caneppele Pereira ${ }^{1}$, Fábio Henrique Krenchinski ${ }^{1}$, Rafaela Alenbrant Migliavacca ${ }^{2}$, Ricardo Victoria Filho ${ }^{2}$

${ }^{1}$ Universidade Federal do Paraná, e-mail: ajpalbrecht@yahoo.com.br, lpalbrecht@yahoo.com.br, viniciuscanepp@gmail.com, fabiohk2@gmail.com,

${ }^{2}$ Universidade de São Paulo - Escola Superior de Agrícola Luiz de Queiroz, e-mail: afmoreirasilva@hotmail.com, rafaelamigliavacca@hotmail.com,rvictori@usp.br

\section{ABSTRACT}

The aim of this study was to evaluate the selectivity of the herbicides chlorimuron-ethyl, metsulfuron-methyl and nicosulfuron, applied in RR/STS soybean. The experiment I consisted of the application of rates $\left(0,15,30,45\right.$ and $60 \mathrm{~g}^{2}$. $\left.\mathrm{i} \mathrm{ha}^{-1}\right)$ of chlorimuron-ethyl. For the experiment II, were applied rates $\left(0 ; 1.8 ; 3.6 ; 5.4\right.$ and $7.2 \mathrm{~g}$ a. $\left.\mathrm{i} \mathrm{ha}^{-1}\right)$ of metsulfuron-methyl. In experiment III, were used rates $\left(0,50,100,150\right.$ and $\left.200 \mathrm{~g} \mathrm{a} . \mathrm{i} \mathrm{ha}^{-1}\right)$ of nicosulfuron. This was a randomized block design with four replications. We evaluated plant height, number of pods per plant, chlorophyll A, B and total, conductivity, vigor and seed germination, yield and thousand seed mass. Data were subjected to regression analysis. In general, the variables analyzed were not affected by herbicide application. The CD $250 \mathrm{RR} / \mathrm{STS}$ soybean cultivar has proven to be highly tolerant to the herbicides chlorimuron-ethyl, metsulfuron-methyl and nicosulfuron.

Keywords: ALS inhibitors, Glycine max, herbicide-tolerant crops, selectivity

\section{EFEITO DA APLICAÇÃO DE SULFONILURÉIAS SOBRE SOJA RR/STS}

\section{RESUMO}

O objetivo do trabalho foi avaliar a seletividade dos herbicidas chlorimuron-ethyl, metsulfuron-methyl e nicosulfuron, aplicados em soja RR/STS. O experimento I constituiu-se da aplicação de doses $\left(0,15,30,45\right.$ e $60 \mathrm{~g}$ i. a. ha $\left.{ }^{-1}\right)$ de chlorimuron-ethyl. Para o experimento II foram aplicadas doses $\left(0 ; 1,8 ; 3,6 ; 5,4\right.$ e 7,2 g i. a. ha $\left.{ }^{-1}\right)$ de metsulfuron-methyl. Para o experimento III foram aplicadas doses $\left(0,50,100,150\right.$ e $200 \mathrm{~g}$ i. a. ha $\left.{ }^{-1}\right)$ de nicosulfuron. Foi empregado delineamento experimental em blocos casualizados, com quatro repetições. Foram avaliadas: altura de planta, número de vagens por planta, clorofila A, B e total, condutividade, vigor e germinação das sementes, produtividade e massa de mil sementes. Os dados foram submetidos à análise de regressão. De maneira geral, as variáveis analisadas não sofreram 
influência pela aplicação dos herbicidas. O cultivar de soja CD 250 RR/STS apresentou-se tolerante aos herbicidas chlorimuron-ethyl, metsulfuron-methyl e nicosulfuron.

Palavras-chave: Culturas tolerantes a herbicidas, Glycine max, inibidores da ALS, seletividade

\section{INTRODUCTION}

It is remarkable the growth of areas occupied by soybean crops in Brazil; in the 2015/2016 growing season, it reached 32.18 million hectares (COMPANHIA NACIONAL DE ABASTECIMENTO - CONAB, 2016). Another important aspect is that RR (Roundup Ready) soybean crops corresponded to $93.5 \%$ of the total soybean area in Brazil in the 2014/2015 season (CÉLERES, 2015).

Considering the role of the soybean complex in the world scenario, the researches aimed at increasing the quality and quantity produced of this grain are intense. This has required the constant reformulation and adaptation of technologies and management, as a more adequate positioning of the herbicide glyphosate, in addition to the emergence of new technologies.

Sulfonylurea-tolerant soybean (STS) is not a transgenic crop as it has been developed through the seed mutagenesis technique using the ethyl methanesulfonate (EMS) alkylating agent, which is an agent that does not cause mutation by insertion into the DNA, but by the modification of the already present base, by introducing an alkyl radical. In this case an ethyl, often in the nitrogenous base Guanine (ROGOZIN et al., 2001).

Mutant seeds of the 'Williams 82' soybean cultivar were selected according to tolerance to chlorsulfuron sulfonylurea. Thus, the soybean cultivar W20 was developed, which presented a high degree of tolerance, in post and pre-emergence, for some sulfonylureas. Research has shown that this characteristic is determined by a semi-dominant allele that has been designated Als1. Studies such as these are of fundamental importance to identify other mutations, and consequently to increase the tolerance of these soybean cultivars to sulfonylureas and other ALSinhibiting herbicide families (SEBASTIAN et al., 1989; GHIO et al., 2013; WALTER et al., 2014). STS cultivars tolerate up to four times higher rates of chlorimuron-ethyl than those recommended for non-tolerant cultivars, without significant damage (COODETEC, 2011; ROSO \& VIDAL, 2011).

The chemical group of sulfonylureas was discovered and initially developed by Du Pont de Nemours \& Company in 1975 and the first commercial product was chlorsulfuron in 1981 
(OLIVEIRA JR, 2011). Herbicides of this group act via inhibition of acetolactate synthase (ALS), irreversibly. ALS is the initial biosynthesis enzyme of the branched-chain amino acids valine, leucine and isoleucine, catalyzing two parallel reactions, pyruvate condensation, to form acetolactate; and condensation of pyruvate with 2-oxybutyrate, to form acetohydroxybutyrate (EBERLEIN et al., 1997). These amino acids, valine, leucine and isoleucine, are required for the production of new cells and also for essential components in proteins (VIDAL, 1997; ZHOU et al., 2007).

Sulfonylureas mainly control dicotyledonous weeds but some molecules demonstrate good action against grasses. Thus, they are widely used to control weeds in wheat, rice, soybean, barley, cotton, potato and corn crops (BROWN, 1990; ZHOU et al., 2007).

In this way, the goal of the present work was to evaluate the selectivity of three herbicides of the sulfonylurea group: chlorimuron-ethyl, metsulfuron-methyl and nicosulfuron applied in post-emergence (V4) of the CD 250 RR/STS soybean cultivar.

\section{MATERIAL AND METHODS}

Three experiments were carried out in production area, in the municipality of Marialva (north central region of the state of Paraná), in the 2011/12 growing season. According to Köppen climate classification, the predominant climatic type is $\mathrm{Cfa}$ - mesothermal humid subtropical. This type of climate is characterized by the predominance of hot summers, low frequency of severe frosts and a tendency of rainfall concentration in the summer (INSTITUTO AGRONÔMICO DO PARANÁ - IAPAR, 1987).

Fertilization practices, crop planting and phytosanitary management were carried out according to the recommendations of Empresa Brasileira de Pesquisa Agropecuária EMBRAPA (2011). Fertilization was carried out to amend the soil, considering the extraction of the crop. And all plots were kept free of weed interference, by manual weeding.

The cultivar CD 250 RR/STS was used, with indeterminate growth habit, relative maturity group 5.5, resistance to frogeye leaf spot, powdery mildew and stem canker. It is adapted to the southern region of Brazil, Paraguay and regions of the states of Mato Grosso do Sul and São Paulo, with recommended sowing from September $20^{\text {th }}$ to December $10^{\text {th }}$ and plant population of 200 to 300 thousand plants ha ${ }^{-1}$ (COODETEC, 2012).

Experiment I consisted of the application of increasing rates $(0,15,30,45$ and $60 \mathrm{~g}$ a. i. $\left.\mathrm{ha}^{-1}\right)$ of the herbicide chlorimuron-ethyl. For the experiment II, rates of metsulfuron-methyl $(0$, 
1.8, 3.6, 5.4 and $7.2 \mathrm{~g}$ a. i. ha $\left.{ }^{-1}\right)$ were applied. While for experiment III, were used the application of five increasing rates $\left(0,50,100,150\right.$ and $200 \mathrm{~g}$ a. i. ha $\left.{ }^{-1}\right)$ of the herbicide nicosulfuron. For the three experiments the sowing was performed in the first week of November 2011, and the harvest in the last week of February 2012.

The experimental design used in the three experiments was the randomized blocks design, with four replications. The experimental units consisted of $5 \mathrm{~m}$ long plots and six soybean rows, and the four central rows were considered the working area, disregarding the first and last meter of the plot.

Herbicides were applied with a $\mathrm{CO}_{2}$ pressurized backpack sprayer with bar equipped with four spray nozzles, at a constant pressure of $2 \mathrm{Bar}$, a flow rate of $0.65 \mathrm{~L} \mathrm{min.}^{-1}$, working at a height of $50 \mathrm{~cm}$ from the target, and at a speed of $1 \mathrm{~m} \mathrm{~s}^{-1}$, reaching an applied strip of $50 \mathrm{~cm}$ wide per spray nozzle, and providing a spray volume of $200 \mathrm{~L} \mathrm{ha}^{-1}$.

Crop injury was evaluated by means of visual evaluations which assigned percentage scores ranging from 0 to $100 \%$ to each experimental unit (where 0 is the absence of injuries and $100 \%$, death of plants), considering, in this case, symptoms significantly visible in plants, according to their development (SOCIEDADE BRASILEIRA DA CIÊNCIA DAS PLANTAS DANINHAS - SBCPD, 1995). This evaluation was performed at 7, 14, 21 and 28 days after application (DAA).

Variables related to agronomic performance (plant height, number of pods per plant, yield, and 100-seed mass) were evaluated.

The height was analyzed when the plants reached the R7 stage. For the determination of this variable, 10 plants were randomly selected in the working area of the plots, and measured using a millimeter ruler of wood, with the results expressed in centimeters. The number of pods per plant was evaluated at full maturity (stage R8) by manually counting the number of pods also in 10 plants randomly chosen in the working area of each plot.

Plants were harvested from the three central rows, discarding the first and last meter of the plot, totaling a harvested area of $4.05 \mathrm{~m}^{2}$. The plants were at the R8 stage, that is, $95 \%$ of the pods had the typical mature pod color (FEHR et al., 1971). Pods were then threshed in an experimental thresher, cleaned with sieves and packed in paper bags for further analysis and evaluation. Grains produced in each plot had their mass measured and the moisture corrected to 
$13 \%$, from these data we calculated the yield. For the 100-seed mass, the mass of two subsamples were determined per plot and the moisture corrected to $13 \%$.

The content of chlorophyll A, B and total chlorophyll was also evaluated in the two main experiments when the soybean was at the R2 development stage using an electronic chlorophyll content meter (ClorofiLOG). This device measures the absorption of light by the leaf at specific wavelength, the Falker chlorophyll content is determined through the absorption ratios at the different frequencies; this value is highly correlated with laboratory measurements and considers the presence of chlorophyll A and B (FALKER, 2009).

Germination and vigor of seeds were evaluated according to Brasil (2009) and electric conductivity of seeds according to Loeffler et al. (1988). The germination test was performed using four sub-samples of 50 seeds per field repetition of each treatment, placed to germinate between three sheets of filter paper, moistened with demineralized water, in the proportion of three times the weight of the dry paper. Rolls were made and taken to a germinator chamber set to maintain a constant temperature of $25^{\circ} \mathrm{C}$. The evaluation was performed eight days after assembling the test, computing the percentage of normal seedlings obtained. The seed vigor test was analyzed in conjunction with the germination test, computing the percentage of normal seedlings obtained on the fifth day after assembling the test.

The electrical conductivity test was performed using four replicates of 50 seeds per field repetition of each treatment. The sub-samples were weighed on a precision scale, accurate to three decimal places. Then, they were soaked in a container with $75 \mathrm{~mL}$ distilled water and then kept in a germinator set at $25^{\circ} \mathrm{C}$ for 24 hours. After the period of the test, the electrical conductivity of the soaking solution was measured in a conductivity bridge (conductivity meter) with a constant electrode sensor 1.0. The result obtained in the conductivity meter was divided by the mass of each sub-sample, and the final result was expressed in $\mathrm{dS} \mathrm{m}^{-1}$. After met the basic assumptions for the analysis of variance, data were subjected to regression analysis $(\mathrm{p}<0.05)$, according to Pimentel-Gomes and Garcia (2002).

\section{RESULTS AND DISCUSSION}

For the variables analyzed in experiment I, it was not possible to set a linear regression model for any of these variables according to the observed criteria (biological explanation, 
significant regression, non-significant regression deviations, coefficient of determination and residual analysis).

These results demonstrate the tolerance of the CD 250 RR/STS soybean cultivar to chlorimuron-ethyl, applied in post-emergence (V4) up to a dose of $60 \mathrm{~g}$ a. i. ha ${ }^{-1}$ (Table 1). Figure 1 shows the rainfall and temperature distribution throughout the period of the experiment in the field.

These results corroborate partially those found by Merotto Jr. et al. (2000), who verified a certain tolerance of soybean cultivars to the application of some sulfonylureas even before the STS technology. Reddy \& Whiting (2000) observed that the yield of the DP 3571 S soybean cultivar (sulfonylurea tolerant) was not negatively influenced by the application of chlorimuronethyl (22 g a. i. ha $\left.{ }^{-1}\right)$, in sequential application in early and late post-emergence.

The same trend was found for the other variables analyzed in experiment I; none of them showed a significant difference at $5 \%$ probability $(\mathrm{p}<0.05)$, which allowed the adequate fit of a regression model.

Table 1. Response of the variables to the application of chlorimuron-ethyl (experiment I). Marialva, State of Paraná, 2011/12 growing season.

\begin{tabular}{ccccccccccc}
\hline $\begin{array}{c}\text { Rates } \\
\left(\mathrm{g} \mathrm{a.} \mathrm{i.} \mathrm{ha}{ }^{-1}\right)^{*}\end{array}$ & $\mathrm{H}$ & NPP & Yield & SM & CloA & CloB & CloT & EC & VIG & GER \\
\hline 0 & 64.50 & 18.79 & 1302.29 & 11.33 & 30.30 & 8.52 & 38.83 & 163.30 & 54.00 & 60.00 \\
\hline 15 & 66.34 & 20.25 & 1249.40 & 11.47 & 30.68 & 7.77 & 38.43 & 146.76 & 64.25 & 70.00 \\
\hline 30 & 66.34 & 21.54 & 1526.76 & 11.27 & 31.04 & 8.03 & 39.05 & 153.90 & 54.75 & 64.00 \\
\hline 45 & 66.42 & 22.46 & 1459.65 & 11.64 & 31.33 & 8.28 & 39.60 & 183.18 & 49.00 & 56.25 \\
\hline 60 & 66.79 & 21.29 & 1467.45 & 11.77 & 29.89 & 7.47 & 37.33 & 166.17 & 50.00 & 59.75 \\
\hline Mean & 66.08 & 20.87 & 1401.11 & 11.50 & 30.65 & 8.01 & 38.65 & 162.66 & 54.40 & 62.00 \\
\hline C.V. $(\%)$ & 6.10 & 11.90 & 16.33 & 5.01 & 4.35 & 6.23 & 4.17 & 30.58 & 39.02 & 30.39 \\
\hline
\end{tabular}

${ }^{*}$ Grams of active ingredient per hectare.

H: plant height (cm), NPP: number of pods per plant ${ }^{-1}$, yield ( $\left.\mathrm{kg} \mathrm{ha}^{-1}\right)$, SM: 100-seed mass (g), CloA: chlorophyll A, CloB: chlorophyll B, CloT: total chlorophyll, EC: electrical conductivity ( $\left.\mathrm{dS} \mathrm{m}{ }^{-1}\right)$, VIG: vigor (\%) and GER: seed germination $(\%)$. 


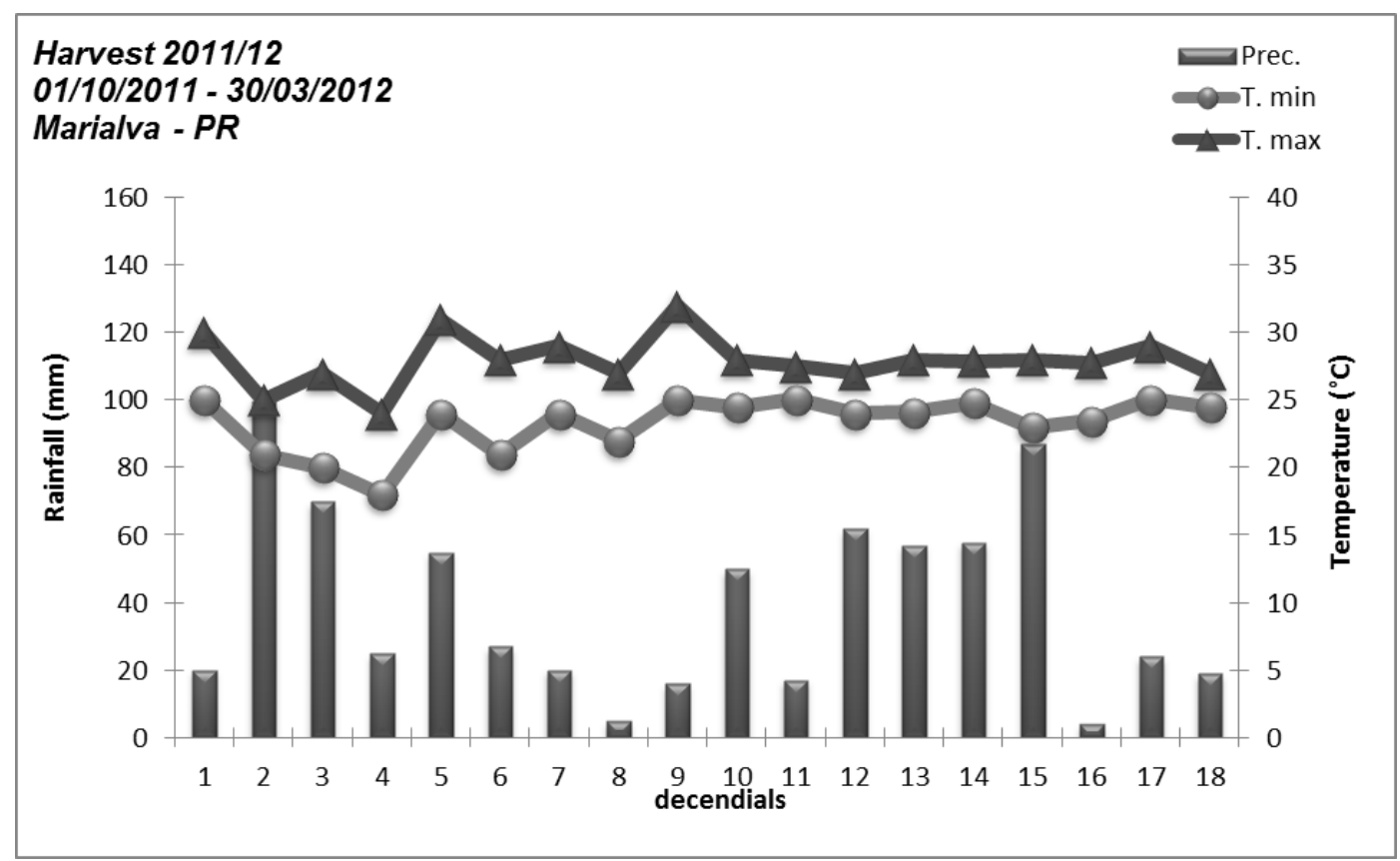

Figure 1. Rainfall, minimum average temperature and maximum average temperature for the period referring to the soybean crop cycle, in the municipality of Marialva, in the 2011/12 harvest. Source: INMET

For the application of metsulfuron-methyl rates, it was possible to fit a negative linear regression for the chlorophyll A, B and total, as shown in Figure 2, indicating minor injuries with increasing rates; these injuries were not perceived visually. However, the increase of rates of this herbicide did not significantly interfere with development and productivity, as well as with variables related to seed quality (Table 2).

With increasing rates of metsulfuron-methyl, there was a decline in chlorophyll in RR/STS soybean plants, demonstrating that high rates of this herbicide could cause injuries to the plant. Merotto Jr. et al. (2000) compared the tolerance of soybean cultivars to metsulfuron-methyl and found that even the cultivar tolerant to this herbicide showed yield at higher rates, which is related to the lower concentration of chlorophyll, causing chloroses.

Walker et al. (1994) analyzed soybean cultivars that showed tolerance to ALS inhibitors, and verified a decrease in initial plant growth at 10 days after application, but these plants recovered up at 21 and 30 DAA.

However, the low percentage of germination can be attributed to infestation of some fungi in seed storage, such as Phomopsis spp. and Fusarium semitectum (FRANÇA NETO \& HENNING, 1992). 



Figure 2. Variation in chlorophyll A (a), chlorophyll B (b) and total chlorophyll (c) of RR/STS soybean plants according to the application of rates of metsulfuron-methyl. Marialva, State of Paraná, 2011/12 growing season.

Table 2. Response of the variables to the application of metsulfuron-methyl (experiment II). Marialva, State of Paraná, 2011/12 growing season.

\begin{tabular}{cccccccc}
\hline $\left.\begin{array}{c}\text { Rates } \\
(\mathrm{g} \mathrm{a.} \mathrm{i.} \mathrm{ha}\end{array}\right)^{*}$ & $\mathrm{H}$ & NPP & Yield & SM & CloA & CloB & CloT \\
\hline 0 & 68.58 & 23.59 & 1474.29 & 11.26 & 149.87 & 57.00 & 66.00 \\
\hline 1.8 & 71.88 & 24.33 & 1368.29 & 10.51 & 187.06 & 49.50 & 57.25 \\
\hline 3.6 & 68.38 & 24.34 & 1441.58 & 10.92 & 159.18 & 55.25 & 60.25 \\
\hline 5.4 & 65.71 & 22.68 & 1197.38 & 10.81 & 167.64 & 56.75 & 63.00 \\
\hline 7.2 & 67.38 & 22.67 & 1357.20 & 10.90 & 191.14 & 48.50 & 52.50 \\
\hline Mean & 68.38 & 23.52 & 1367.75 & 11.08 & 170.98 & 53.40 & 59.80 \\
\hline C.V. $(\%)$ & 4.32 & 12.94 & 15.22 & 6.31 & 21.44 & 33.85 & 28.48 \\
\hline
\end{tabular}

*Grams of active ingredient per hectare.

H: plant height (cm), NPP: number of pods per plant ${ }^{-1}$, yield $\left(\mathrm{kg} \mathrm{ha}^{-1}\right)$, SM: 100-seed mass (g), CloA: chlorophyll A, CloB: chlorophyll B, CloT: total chlorophyll, EC: electrical conductivity ( $\mathrm{dS} \mathrm{m} \mathrm{m}^{-1}$ ), VIG: vigor (\%) and GER: seed germination $(\%)$. 
When applied increasing rates of nicosulfuron, a positive linear regression was fit for electrical conductivity (Figure 3a), as well as a negative linear regression for vigor and seed germination (Figures 3b, c). However, for other variables analyzed in this experiment, it was not possible to fit a linear regression model for any of these variables according to the observed criteria (biological explanation, significant regression, non-significant regression deviations, coefficient of determination and residual analysis) (Table 3). These results demonstrate the tolerance of the CD $250 \mathrm{RR} / \mathrm{STS}$ soybean cultivar to the herbicide nicosulfuron, applied in a post-emergence (V4) up to a dose of $200 \mathrm{~g}$ i. a. ha ${ }^{-1}$.

Manley et al. (2001) verified injuries in the cultivars W20 STS, Asgrow 9122 STS, Asgrow 3200 STS, Asgrow 4045 STS, caused by the application of nicosulfuron ( $35 \mathrm{~g} \mathrm{i.} \mathrm{a.} \mathrm{ha-1)}$ in early post-emergence. The percentages of injury varied from 24 to 45 , however in general no reductions in yield were observed during the four years of cultivation.

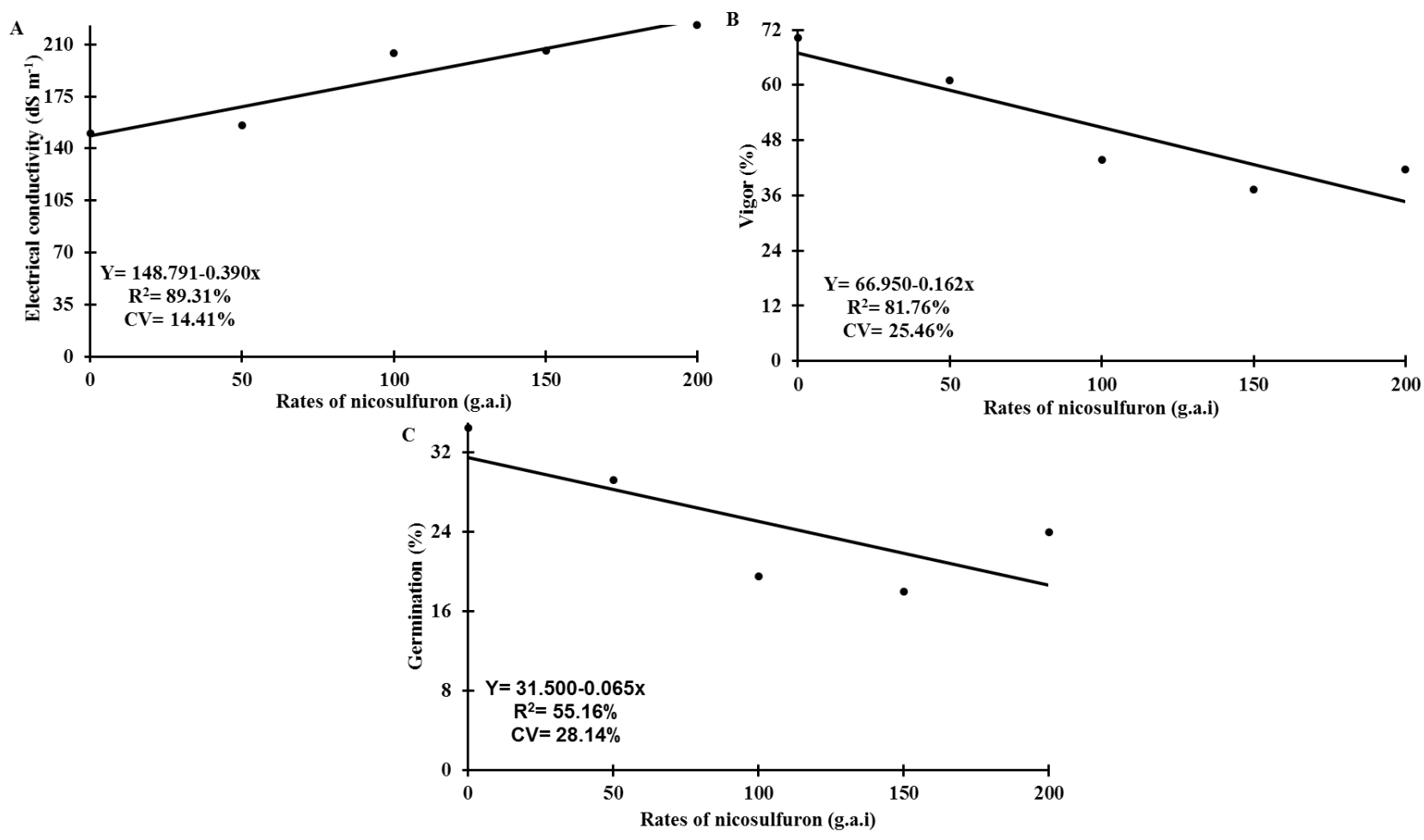

Figure 3. Variation in electrical conductivity (a), vigor (b) and germination (c) of seeds of RR/STS soybean plants according to the application of rates of nicosulfuron. Marialva, State of Paraná, 2011/12 growing season. 
Table 3. Response of the variables to the application of nicosulfuron (experiment III). Marialva, State of Paraná, 2011/12 growing season.

\begin{tabular}{cccccccc}
\hline $\begin{array}{c}\text { Rates } \\
(\mathrm{g} \mathrm{a.} \mathrm{i.} \mathrm{ha})^{-1}\end{array}$ & H & NPP & Yield & SM & CloA & CloB & CloT \\
\hline 0 & 68.25 & 21.54 & 1438.00 & 11.79 & 29.61 & 8.02 & 37.63 \\
50 & 67.79 & 23.35 & 1410.13 & 11.29 & 29.42 & 7.05 & 36.43 \\
\hline 100 & 68.09 & 26.04 & 1306.33 & 10.97 & 29.45 & 7.57 & 36.95 \\
\hline 150 & 66.83 & 24.63 & 1140.32 & 11.36 & 30.55 & 7.99 & 38.53 \\
\hline 200 & 67.29 & 23.54 & 1137.31 & 11.48 & 29.65 & 8.19 & 37.83 \\
\hline Mean & 67.65 & 23.80 & 1286.41 & 11.38 & 29.73 & 7.76 & 37.47 \\
\hline C.V. (\%) & 4.53 & 12.81 & 18.47 & 5.06 & 5.32 & 9.83 & 5.71 \\
\hline
\end{tabular}

${ }^{*}$ Grams of active ingredient per hectare.

H: plant height (cm), NPP: number of pods per plant ${ }^{-1}$, yield $\left(\mathrm{kg} \mathrm{ha}^{-1}\right)$, SM: 100-seed mass (g), CloA: chlorophyll A, CloB: chlorophyll B, CloT: total chlorophyll, EC: electrical conductivity (dS $\left.\mathrm{m}^{-1}\right)$, VIG: vigor (\%) and GER: seed germination $(\%)$.

Higher rates of this sulfonylurea cause damage to the physiological quality of soybean seeds (non-STS cultivars), and a decrease in germination and vigor can be observed, as well as an increase in salinity through the measurement of the electrical conductivity, impairing the quality of this seed. High rates of this herbicide can cause deleterious effects even to plants that are tolerant to it, as observed by Dan et al. (2010) in maize hybrids subjected to high rates of nicosulfuron.

In order to evaluate the effect of the herbicide on the quality of seeds, it is necessary to consider the phenological stage of the plant when dealing with pre-harvest desiccation (GUIMARÃES et al., 2012). In the present case that employed technology that confers tolerance to the group of sulfonylureas, the factor that interfered with the quality was high rates of nicosulfuron.

Crop injury was evaluated in the three experiments at 7, 14, 21 and 28 DAA. However, no percentage scores were recorded, since the soybean plants showed no symptoms of injury, results in accordance with those observed for most of the other variables.

It should also be noted that the low yields for the three experiments can be explained by the low rainfall in the month of December, during the end of the vegetative period and the beginning of the soybean reproductive period. 
The high tolerance of the CD 250 RR/STS cultivar to the application of chlorimuron-ethyl is shown, up to the maximum rate used $\left(60 \mathrm{~g}\right.$ a. i. ha $\left.{ }^{-1}\right)$. The maximum recommended rate of chlorimuron-ethyl for non-STS soybean cultivars is $20 \mathrm{~g}$ i. a. $\mathrm{ha}^{-1}$ (RODRIGUES \& ALMEIDA, 2011), that is, three times lower than the maximum dose tested in this study. According to Roso \& Vidal (2011), STS cultivars tolerate rates up to four times higher than the maximum recommended dose of chlorimuron-ethyl. The herbicides metsulfuron-methyl and nicosulfuron have no records for application in soybean (RODRIGUES \& ALMEIDA, 2011), nor is there an exact decision on the use of these and other sulfonylureas in STS soybeans. In general, the results presented herein indicate tolerance of the CD $250 \mathrm{RR} / \mathrm{STS}$ cultivar to the application of metsulfuron-methyl and nicosulfuron, up to the rates of 7.2 and $200 \mathrm{~g}$ a. i. ha $^{-1}$. Studies like this are of great importance in decision making about the use of sulfonylureas in STS soybeans.

Nevertheless, it is necessary to continue the investigation on STS materials, with the use of different sulfonylureas, different genotypes and multiple soil and climate conditions, aiming to gather information that may support the safe positioning of this technology, as there are rare reports in the literature on this technology, which has great potential of use by farmers in the management of weeds.

\section{CONCLUSIONS}

The CD $250 \mathrm{RR} / \mathrm{STS}$ soybean cultivar was tolerant to the herbicides chlorimuron-ethyl, metsulfuron-methyl and nicosulfuron at the recommended rates. However, with the addition of nicosulfuron and metsulfuron-methyl, injuries may be observed in some variables under the study conditions.

\section{ACKNOWLEDGEMENTS}

We would like to thank the farmers Alfredo Albrecht and Eduardo de Pintor for collaboration and support during the setup and conduction of the experiments.

\section{REFERENCES}

BRASIL. Ministério da Agricultura, Pecuária e Abastecimento. 2009. Regras para análise de sementes. Brasília: Secretaria de Defesa Agropecuária, 398p.

BROWN, H. M. 1990. Mode of action, crop selectivity, and soil relations of the sulfonylurea herbicides. Pesticide Science, Hoboken, v.29, p.263-281.

CÉLERES. 2015. Informativo biotecnologia: safra 2014/2015, terceiro levantamento, julho de 
2015. Uberlândia, 7p.

CONPANHIA NACIOANAL DE ABASTECIMENTO - CONAB. 2016. Acompanhamento da safra brasileira: grãos: safra 2015/2016, nono levantamento, junho de 2016. Brasília, 174p.

COODETEC. 2011. Sistema STS. Available at: <http://www.coodetec.com.br/sts/> . Acesso em: 21 de maio de 2014.

COODETEC. 2012. 2012 - Guia de produtos. Available at: <http://www.coodetec.com.br/downloads/Guia_de_produtos_Soja_Sul_e_Paraguai.pdf>. Access in: 11 jul. 2015.

DAN, H. A.; BARROSO, A. L. L.; BRAZ, G. B. P.; DAN, L. G. M.; FERREIRA FILHO, W. C.; MENEZES, C. C. E. 2010. Seletividade do nicosulfuron e da mistura com atrazine na cultura do milho. Revista Agrarian, Dourados, v.3, p.243-252.

EBERLEIN, C. V.; GUTTIERI, M. J.; MALLORY-SMITH, C. A.; THILL, D. C.; BAERG, R. J. 1997. Altered acetolactate synthase activity in ALS - inhibitor resistant prickly lettuce (Lactuca serriola). Weed Science, Lawrence, v.45, p.212-217.

EMPRESA BRASILEIRA DE PESQUISA AGROPECUÁRIA - EMBRAPA. 2011. Tecnologias de produção de soja: região central do Brasil 2012 e 2013. Londrina: Embrapa Soja, 262p.

FALKER. 2009. Medidor Eletrônico de Teor de Clorofila - clorofiLOG. Available at: <http://www.falker.com.br/Produto.php?id=4>. Access in: 28 jan. 2016.

FEHR, W. R.; CAVINESS, C. E.; BURMOOD, D. T.; PENNINGTON, J. S. 1971. Stage of development description for soybean, Glycine max (L.) Merrill. Crop Science, Malden, v.11, p.929-931.

FRANÇA NETO, J. B.; HENNING, A. A. 1992. DIACOM: diagnóstico completo da qualidade da semente de soja. Londrina: Embrapa-CNPSo, 22p.

GHIO, C.; RAMOS, M. L.; ALTIERI, E.; BULOS, M; SALA, C. A. 2013. Molecular characterization of Als1, an acetohydroxyacid synthase mutation conferring resistance to sulfonylurea herbicides in soybean. Theoretical and Applied Genetics, Stuttgart, v.126, p.2957-2968.

GUIMARÃES, V. F.; HOLLMANN, M. J.; FIOREZE, S. L.; ECHER, M. M. ; RODRIGUESCOSTA, A. C. P.; ANDREOTTI, M. 2012. Produtividade e qualidade de sementes de soja em função de estádios de dessecação e herbicidas. Planta Daninha, Viçosa, v.30, p.567-573.

INSTITUTO AGRONÔMICO DO PARANÁ - IAPAR. 1987. Cartas climáticas básicas do Estado do Paraná. Londrina, 35p.

LOEFFLER, T. M.; TEKRONY, D. M.; EGLI, D. B. 1988. The bulk conductivity test as an indicator of soybean seed quality. Journal of Seed Technology, Moline, v.12, p.37-53.

MANLEY, B. S.; WILSON, H. P.; HINES, T. E. 2001. Weed management and crop rotations influence populations of several broadleaf weeds. Weed Science, Lawrence, v.49, p.106-122.

MEROTTO JÚNIOR, A.; VIDAL, R. A.; FLECK, N. G. 2000. Tolerância da cultivar de soja Coodetec 201 aos herbicidas inibidores de ALS. Planta Daninha, Viçosa, v.18, p. 93-102.

OLIVEIRA JÚNIOR, R. S. 2011. Mecanismos de Ação dos Herbicidas. In: OLIVEIRA JÚNIOR, R. S.; CONSTANTIN, J.; INOUE, M. H.; (ed.). Biologia e Manejo de Plantas Daninhas. Curitiba: Omnipax, p.141-192

PIMENTEL-GOMES, F.; GARCIA, C. H. 2002. Estatística aplicada a experimentos agronômicos e florestais: exposição com exemplos e orientações para uso de aplicativos. Piracicaba: FEALQ, 309p.

REDDY; K. N.; WHITING, K. 2000. Weed Control and Economic Comparisons of GlyphosateResistant, Sulfonylurea-Tolerant, and Conventional Soybean (Glycine max) Systems. Weed Technology, Lawrence, v.14, p.204-211. 
RODRIGUES, B. N.; ALMEIDA, F. S. 2011. Guia de Herbicidas, $6^{\mathrm{a}}$ ed. Londrina: Edição dos autores, 697p.

ROGOZIN, I. B.; BERIKOV, V. B.; VASUNINA, E. A.; SINITSINA, O. I. 2001. The effect of the primary structure of DNA on induction of mutations by alkylating agents. Russian Journal of Genetics, Moscou, v.37, p.704-710.

ROSO, A. C.; VIDAL, R. A. 2011. Culturas resistentes aos herbicidas inibidores da enzima ALS: Revisão de literatura. Revista de Ecotoxicologia e Meio Ambiente, Curitiba, v.21, p.13-24.

SOCIEDADE BRASILEIRA DA CIÊNCIA DAS PLANTAS DANINHAS - SBCPD. 1995. Procedimentos para instalação, avaliação e analise de experimentos com herbicidas. Londrina: SBCPD, 42p.

SEBASTIAN, S. A.; FADER, G. M.; ULRICH, J. F.; FORNEY, D. R.; CHALEFF, R. S. 1989. Semi-dominant soybean mutation for resistance to sulfonylurea herbicides. Crop Science, Malden, v.29, p.1403-1408.

VIDAL, R. A. 1997. Herbicidas: mecanismo de ação e resistência de plantas. Porto Alegre: Palotti, 165p.

WALKER, L. M.; HATZIOS, K. K.; WILSON, H. P. 1994. Absorption, Translocation, and Metabolism of ${ }^{14} \mathrm{C}$-Thifensulfuron in Soybean (Glycine max), Spurred Anoda (Anoda cristata), and Velvetleaf (Abutilon theophrasti). Journal of Plant Growth Regulation, Dresden, v.13, p.27-32.

WALTER, K. L.; STRACHAN, S. D.; FERRY, N. M.; ALBERT, H. H.; CASTlE, L. A.; SEBASTIAN, S. A. 2014. Molecular and phenotypic characterization of Als1 and Als2 mutations conferring tolerance to acetolactate synthase herbicides in soybean. Pest Management Science, Hoboken, v.70, p.1831-1839.

ZHOU, Q.; LIU, W.; ZHANG, Y.; LIU, K. K. 2007. Action mechanisms of acetolactate synthase-inhibiting herbicides. Pesticide Biochemistry and Physiology, Amherst, v.89, p.8996. 